Urszula Kowalska

ula.kowalska@poczta.onet.pl

\title{
Obecność romantyzmu: co i jak czyta Danny Smiřrický?
}

\begin{abstract}
Kowalska Urszula, Obecność romantyzmu: co i jak czyta Danny Smiřický? (The presence of Romanticism: what and how does Danny Smiřický read?). „Poznańskie Studia Slawistyczne” 1. Poznań 2011. Rys Press, pp. 145-159. ISSN 2084-3011.
\end{abstract}

The main purpose of the article is to identify and recognize ways of reinterpretating romantic heritage throughout a wide historical and literary context. The thesis concentrates on a novel written by Josef Škvorecký, entitled Př́iběh inženýra lidských duší , which deals with the themes of the history of emigration, totalitarianism and literature, which can be helpful in elucidating unexplained experiences. It is necessary to consider dependent relationships and connections between history and older literature. The main character of Škvoreský's story, Danny Smiřický, is a Czech emigrant working as a lecturer at a Canadian university. The experience of reading proves to him just how universal and significant literature can be. The literary works of Edgar Allan Poe and Nathaniel Hawthorne become the way of "translating" Czech experience with communism for Canadian students. An hour of literature range into an hour of history.

Keywords: Romanticism, history, literature, reinterpretation, reading, Emigration, Danny Smiřický. 
Wybór bohatera literackiego i postaw przez niego reprezentowanych, a tym samym $i$ wybór literackiego patrona byt jednym z decydujacych epizodów życiorysu romantyka-zarówno poety, jak i stworzonej przez niego postaci człowieka współczesnego ${ }^{l}$.

W jednym z wywiadów Josef Škvorecký wspomniał: „Czytam książki jako wiadomości od człowieka, którego lubię"2. Twórczość innych autorów ma wyraźny wpływ na jego pisarstwo, zaś obfita intertekstualność utworów przez niego pisanych i konieczność poszukiwania literackich śladów w każdym tekście wymaga od czytelnika śledzenia inspiracji i konsekwentnych odniesień do konkretnej literatury. Na czele z twórczością anglojęzyczną.

Zasugerowana w tytule refleksja nad współczesną lekturą utworów powstałych $\mathrm{w}$ okresie romantyzmu łączy się z potrzebą podkreślenia, widocznego w twórczości Škvoreckiego, wpływu literatury na konkretną osobę - bohatera, który niewątpliwie jest bohaterem czytającym, postrzegającym przez pryzmat przeczytanych książek swoje życie, a przeczytane książki interpretującym przez pryzmat własnych doświadczeń3. Czyta i przeżywa literackie rzeczywistości na nowo, odnajdując w nich siłę, natchnienie, całą gamę uczuć, refleksji i bodźców, skłaniających do działania. Ta swoista reaktywacja romantycznej roli przypisywanej dziełu literackiemu pozwala zrozumieć wybór lektur, które znajdują się na półce Danny’ego Smiřickiego. A może nawet obarczyć je mianem „książek zbójeckich”? Wśród nich nie mogło za-

1 M. Żmigrodzka, M. Janion, Romantyzm i historia, Warszawa 1978, s. 205.

2 Jazz w małym mieście. Z Josefem Škvoreckim rozmawia Antonín J. Liehm, przeł. T. Grabiński, „Literatura na Świecie” 2007, nr 3-4, s. 318.

3 Kwestia szeroko pojętej romantyczności w pisarstwie Škvoreckiego z pewnością zasługuje na rozwinięcie, któremu niestety nie możemy poświęcić miejsca w tym artykule, skupiającym się na twórczym wykorzystaniu i reinterpretacji dzieł światowego romantyzmu we współczesnym kontekście. Warto jednak chociażby zasygnalizować złożoną konstrukcję głównego bohatera powieści Škvoreckiego, jego sposób czytania $i$ interpretowania nie tylko romantycznych dzieł literackich, rolę literatury i jej wpływ na życie, nie wspominając o martyrologicznych elementach biografii z emigracją (wędrówką, pielgrzymką?) na czele. 
braknąć kanonicznych dzieł światowego romantyzmu, poezji Edgara Allana Poego oraz Szkartatnej litery Hawthorne'a.

Literatura czytana w świecie emigrantów, który sam w sobie jest konfrontacją dwóch wymiarów ${ }^{4}$, staje się trzecim uczestnikiem zderzenia odmiennych rzeczywistości. Postacią obserwującą i opisującą to starcie jest, stworzony przez Josefa Škvoreckiego ,na podobieństwo własne”, Danny Smiřický - główny bohater i jednocześnie narrator powieści Přiběh inženýra lidských duši z ujmującym i wiele thumaczącym podtytułem Entrtejnment na stará témata o životě, ženách, osudu, snění, dělnické tř́dě, fízlech, lásce a smrti ${ }^{5}$.

Danny Smiřický jest niewątpliwie bohaterem czytającym. Jest także nauczycielem akademickim, Czechem z pochodzenia, emigrantem z przymusu, dydaktykiem z wyboru. Żadne cechy charakterystyczne jego wyglądu nie przyciagają szczególnie uwagi. Istotny może być co najwyżej fakt, że Danny’ego, podobnie jak jego (s)twórcy, nie omija prawo przemijania. Wiadomo, że Danny, a razem z nim Josef, starzeją się, zmieniają, dorośleją, dojrzewają i, zarówno fizycznie, jak i mentalnie, rosną. Jak twierdzi Květoslav Chvatík: „Tetralogia o Dannym Smiřickim, to współczesny Bildungsroman, wyjątkowy z tego względu, że zaczął go pisać 24-letni młodzieniec. Proces tworzenia postaci Danny'ego przebiegał więc niemal paralelnie z dojrzewaniem samego autora" ". Wraz z Dannym dojrzewa jego pamięć. W zależności od sytuacji życiowej i, wpływającej na nią, sytuacji geopolitycznej rośnie również jego poczucie bezpieczeństwa albo poczucie zagrożenia. Nieustająco

4 W przypadku twórczości Škvoreckiego konfrontacją starej Europy, czyli kontynentu, na którym historia i polityka to elementy immanentne w życiu człowieka z młodym kontynentem, żyjącym teraźniejszością, niepamiętającym, bo właściwie niemającym o czym pamiętać. Jak pisze Helena Kosková w biografii Josefa Škvoreckiego: „Přiběh se tak stává syntézou celoživotní osobní zkušenosti, ve které je zdůrazněno téma exilu jako setkání a konfrontace dvou světu, kde jiná životní zkušenost vzbuzuje jiné asociace a dává slovům jiné významy” (H. Kosková, Josef Škvorecký, Praha 2004, s. 132).

5 W Polsce powieść ukazała się w tłumaczeniu Andrzeja Sławomira Jagodzińskiego pod tytułem Przypadki inżyniera ludzkich dusz. Entertainment ze starymi tematami życia, kobiet, losu, marzeń, klasy robotniczej, tajniaków miłości i śmierci, Sejny 2008.

6 K. Chvatík, Opowiadacz Škvorecký, przeł. A. S. Jagodziński, „Literatura na Świecie" 2007, nr 3-4, s. 264. 
wzrasta także wiedza Danny'ego na temat świata oraz wiedza na temat niewiedzy innych. Danny trochę siwieje, ale za to jego włosy zyskują niezastapiony dull shine, utrwalony za pomocą dry looku. Co jednak ważniejsze, Danny jest ,obklopen aureolou muže, jenž prožil život v policejních diktaturách a za války byl v protinacistickém odboji”" Nie ma powodów, by wattpić w autobiograficzny fundament postaci Danny'ego - jego przeszłość, sytuacja życiowa, wybory, poglądy, wspomnienia i zachowania implikują odczytywanie przez pryzmat biografii Škvoreckiego pewnych faktów z życiorysu Smiřickiego. Bądź na odwrót.

Według istotnego dla polskiego literaturoznawstwa opracowania, sytuującego romantyzm w kontekście historycznym i historię w kontekście romantycznym, „romantyzm to prąd w kulturze, który życiu każe naśladować literaturę"8. Jak pokazują lektury Smiřickiego, życie upodabnia się do literatury nie tylko w romantyzmie i nie tylko na skutek rozkazu. W poszukiwaniu inspiracji i interpretacji dla niewyjaśnionych zjawisk, wydarzeń społeczno-historycznych oraz niejasnych postaw uczestników tych wydarzeń, z pomocą przychodzi właśnie literatura. Być może nadinterpretowywana lub manipulowana, być może przeceniania, bo przecież operująca dość schematycznymi modelami, których potencjalna powtarzalność w życiu codziennym, w innym czasie i w innej przestrzeni nie wydaje się wcale nieprawdopodobna. Ale jednak w zadziwiający sposób ,paralelna”, mająca drugie dno i dalszy plan, interpretowalna w różnych kontekstach.

\section{Literatura w literaturze, czyli co czyta i o czym opowiada Danny Smiřický}

Twórczość autorów ${ }^{9}$, którym Josef Škvorecký poświęca kolejne rozdziały Př́běhu..., a Danny Smiřický kolejne godziny seminariów, nie jest jedynie przedmiotem uniwersalnych refleksji i skarbnicą cytatów,

\footnotetext{
J. Škvorecký, Př́iběh inženýra lidských duší, cz. I, Praha 1998, s. 23.

M. Żmigrodzka, M. Janion, Romantyzm..., op. cit., s. 6.

Edgar Allan Poe, Nathaniel Hawthorne, Mark Twain, Stephen Crane, Francis Scott Fitzgerald, Joseph Conrad, Howard Phillips Lovecraft.
} 
lecz przede wszystkim punktem wyjścia do skomplikowanej literackiej gry. Intertekstualność powieści nie ogranicza się jednak do erudycyjnego sfunkcjonalizowania wymienionych w rozdziałach utworów. Obok tekstów omawianych na seminariach pojawiają się liczne cytaty, aluzje, motta zaczerpnięte z dzieł literatury światowej, a także rodzime, środkowoeuropejskie konotacje, wśród których, zgodnie z Kroutvorovską tradycją, na pierwszy plan wysuwa się dobrze znana anegdota o Szwejkowskim rodowodzie. W tym swoistym rozgadaniu czy, używając utrwalonego już terminu, w tym swoistym pabitelství pisarstwo Škvoreckiego zbliża się wyraźnie do literackiego potoku słów w wykonaniu Hrabala. Aluzje literackie, cytaty, szeroko pojęta intertekstualność, wnikliwe obserwacje językowe, liczne gry słowne, refleksje lingwistyczne, wielojęzyczność tekstu i formalne innowacje mogą być następstwem estetyki postmodernistycznej, lecz przede wszystkim powstają w wyniku zderzenia języków, tożsamości, światopoglądów i kultur. Tekst, sprawiający wrażenie nieprzekładalnego pod względem językowym, jest w rzeczywistości fragmentem bardzo efektywnie przybliżającym zachodniemu czytelnikowi środkowoeuropejskie doświadczenie. Między innymi dzięki recepcji jego własnej, ,zachodniej” kultury i literatury, uzupełnionej o obcy, „niezachodni” kontekst interpretacyjny. Kolażowość tekstu (kojarzona przez badaczy z estetyką filmowa) sugerowałaby zaś fragmentaryczne postrzeganie rzeczywistości przez głównego bohatera. Pisarstwo Škvoreckiego stara się wydobywać różnorodność i wielowarstwowość epoki, w której żyje autor, podkreśla jej tempo, skłonność do nagłych cięć i zrywów, korespondencję między przeszłością a teraźniejszością, dynamizm, czyli, uogólniając, motywy przewodnie czeskiej i środkowoeuropejskiej historii.

Sam Škvorecký tak określa konstrukcję Přiběhu... oraz proces twórczy towarzyszący powstaniu powieści:

Nahodil jsem epizody, konverzace, images na kousíčky papíru, pak jsem se usadil na podlaze, a jako kdybych dával dohromady gigantickou skládačku, začal jsem těmi útržky minulosti šoupat. Rozdělil jsem je podle kontrastů, podle podobností, spojil jsem je tónem a smyslem; pokoušel jsem se stvořit svět ze zmátku svého života a našeho zmatečného století... Spojil jsem úmy- 
slný zmatek navzájem nesouvislých epizod pomoci několika sérií chronologicky seřazených dopisů od pisatelů z různých životních situaci, přepsal jsem fragmenty z papírků na stránky na stroji, a měl jsem tak před sebou kostru př́běhu. Pak jsem tu kostru začal oblékat do masa slov ${ }^{10}$.

Danny Smiřický, bohater kilku powieści Josefa Škvoreckiego, określany jako alter ego autora, wprowadza podczas seminariów, skierowanych do emigracyjno-tubylczej mieszanki studentów literatury na kanadyjskim uniwersytecie, dzieła, które wywarły znaczący wpływ na jego zawodowe i życiowe wybory. W trakcie poświęconych interpretacji zajęć okazuje się, że wybór dokonany pod wpływem literackich upodobań staje się także wyborem estetyk, postaw i wartości, w których w zdumiewający sposób odbija się biografia bohatera, w szerszym znaczeniu biografia emigranta, a nawet dużej części narodu, do którego ów emigrant przynależy. Odkrycie to implikuje sytuację nieporozumienia pomiędzy wykładowcą a jego studentami, dla których twórczość na przykład Poego czy Hawthorne’a, nie jest nośnikiem uniwersalnych treści, lecz spichlerzem anachronicznych, nieprzystających do współczesności koncepcji wyrażonych dziwnym językiem. W dyskusji ze studentami przeplata się doświadczenie wojny i emigracji, rezonujące w kanadyjskiej teraźniejszości, a jak pisze Květoslav Chvatík: „Centralnym tematem intertekstualnych odniesień i interferencji, wzbogacających tekst o nowe poziomy znaczeniowe pozostaje motyw rewolucji i jej przemiany w okrutną machinę władzy"11.

Pamięć literacka, pojawiająca się obok historycznej i kulturowej, odgrywa niebagatelną rolę w ustawicznym wspominaniu Smiřickiego. Danny, funkcjonujący na co dzień „w zemi měst bez minulosti”12, powraca wspomnieniami do kraju, w którego miastach nie widział przyszłości dla siebie i swojego pisarstwa.

Země je krásná všude. Krásnější je tam, kde je člověku dobře, a dobře je mu tam, kde už nic neodkládá do budoucnosti, protože

\footnotetext{
10 J. Škvorecký, Přiběh neúspěšného saxofonisty, Praha 1997, s. 67.

11 K. Chvatík, Opowiadacz..., op. cit., s. 267.

12 J. Škvorecký, Př́běh inženýra..., cz. I, op. cit., s. 14.
} 
už nemusí a protože z budoucnosti už mnoho nezbývá. Kde pozbyl strachu, protože se není čeho bát... ${ }^{13}$.

Jego duchowe powroty bywają wywołane przez, z pozoru nic nieznaczące, codzienne zdarzenia, wśród których najbardziej „wspomnieniogenną" funkcję pełnią te, związane z osobą zielonookiej studentki, panny Svennson. Co najmniej dwa aspekty każą Danny'emu nawiązać z nią bliższe relacje - jest kobietą i ma na imię Irena. Kanadyjska teraźniejszość w przewrotny sposób wywołuje duchy czeskiej, kosteleckiej przeszłości, w której inna Irena, żyjąca w świecie innych wartości i innych problemów, wzbudzała w narratorze podobne uczucia. Dwie płaszczyzny, dwa równolegle istniejące wymiary, w których obraca się Danny - teraźniejszość i przeszłość - zostają uzupełnione wymiarem trzecim, literackim, niejako spajającym Kostelec z Toronto, Irenę Svennson z przyjaciółką z czasów okupacji, kilkunastoletniego Danny'ego z Dannym około pięćdziesięcioletnim. Literatura interpretowana i omawiana, a właściwie ,przerabiana”, bo to określenie lepiej odda ducha studenckich odczytań podczas seminariów prowadzonych przez Danny'ego Smiřickiego, staje się źródłem niespodziewanych znaczeniowych asocjacji, reminiscencji z czasów, kiedy wspomnienia były dopiero na etapie powstawania. Seminaria ze studentami, którzy swoje pojęcie o literaturze ograniczają do wiedzy nabytej podczas odczytywania splagiatowanej bądź kupionej pracy zaliczeniowej, pogłębiają u Danny’ego poczucie podziału, rozłamu bądź, idąc dalej, schizofreniczności świata, w którym karty rozdaje (raczej niesprawiedliwie) nieprzewidywalna historia. Smiřický rozmowę o literaturze traktuje jako możliwość przekazania uniwersalnych prawd o świecie, które w toku zajęć okazują się coraz mniej uniwersalne. Doświadczenie pochodzące z „europejskiego Theatrum Mundi”, jak narrator nazywa Europę Środkową, nijak się ma do telewizyjnej rzeczywistości, przez której pryzmat obserwują świat „kanadyjskie dzieci prerii”. Tym słuszniejsza wydaje się decyzja o wyborze klasycznych dzieł literatury anglojęzycznej, wedle Smiřickiego interpretowalnych wielopłaszczyznowo i jednocześnie bliższych zachodniemu odbiorcy.

13 Ibidem. 
A já tedy podlehl bláhovému sklonu udělat ze čtverce kruh a pošetilé snaze ukázat zcela iracionální Irence a zcela prérijním dětem z Edenvaleské koleje, že, jak praví Hemingway, je-li něco napsáno dobře, může to mít mnoho významů ${ }^{14}$.

Próba przekazania studentom własnych doświadczeń za pomocą literatury, która przynajmniej z definicji powinna być im bliska, wynika z dość idealistycznego przekonania, towarzyszącego Danny’emu, że w swoim życiu i w kształtowaniu własnych światopoglądów jego podopieczni nie muszą zaczynać od zera, nie muszą popełniać cudzych błędów. Jak pisze Helena Kosková:

Nostalgie stárnoucího vypravěče není tedy jen pocitem ztráty domova a vlastního mládí, ale částečně i výrazem bezvýchodnosti snahy předat studentům něco $\mathrm{z}$ vlastní zkušenosti ${ }^{15}$.

Nieprzekraczalna bariera, mentalna żelazna kurtyna sprawia, że Danny rozpoczyna każdy wykład, nie wiedząc, jak to ws zystko wytłumaczyć. Przenosi na studentów własne doświadczenia i orientuje się, że rzeczywistość, której istnienie próbuje im zasygnalizować, jest dla nich czymś w rodzaju filmu, przedstawienia, niedotyczącej ich fikcji. Przepaść między dziećmi Kanady a dziećmi Pragi jest nie do pokonania. ,Żelazna kurtyna głupoty” (jak opisowo nazywa Smiřický barierę dzielącą jego i studentów), momentami ignorancji, a momentami zwykłej niewiedzy, owocującej na przykład tym, że nazwisko Lovecraft kojarzy się Irenie jedynie z popularną siecią sex shopów, pogłębia w Dannym poczucie nostalgii, będącej pierwotnie rezultatem utraty ojczyzny i własnej młodości. Przebiegła koncepcja, zakładająca użycie literatury amerykańskiej jako pośrednika, który ma uczynić środkowoeuropejskie doświadczenie bardziej zrozumiałym dla zachodniego czytelnika, to przede wszystkim pomysł na urozmaicenie i uprzystępnienie formuły seminaryjnych spotkań. Eksperyment zasadzony na thumaczeniu własnego doświadczenia literaturą udowadnia ,nieprzekładalność” oraz „,niepodzielność" osobistych przeżyć. Specyficznie rozumiane seminarium

14 Ibidem, s. 17.

15 H. Kosková, Josef..., op. cit., s. 136. 
rozgrywa się jednak także pomiędzy twórcą i odbiorcą powieści, a gra, zakładająca istnienie odbicia własnej biografii w dziełach siedmiu pisarzy, pozostaje przede wszystkim przesyconą aluzjami i cytatami intertekstualną szaradą dla czytelnika. Doświadczenie z innego czasu i innej długości geograficznej w niespodziewany sposób koresponduje z dziełami wybranych autorów. Podobnie jak literackie postawy sprzed wieku okazują się pierwowzorem współczesnych, dwudziestowiecznych zachowań. Literackie płaszczyzny zazębiają się. Usamodzielnione, pobudzone przez czytane dzieła, wspomnienia oraz seminaryjne refleksje Danny'ego i jego studentów na temat literatury, same stają się literaturą.

\section{Edgar Allan Poe}

Then, upon the velvet sinking, I betook myself to linking Fancy unto fancy, thinking what this ominous bird of yoreWhat this grim, ungainly, ghastly, gaunt, and ominous bird of yore Meant in croaking 'Nevermore'16.

Na początku grudnia, ściślej „,in the bleak December”, studenci stykają się podczas seminariów prowadzonych przez Danny'ego z twórczością Edgara Allana Poego, szczególną uwagę poświęcając przygodom Pyma oraz tajemniczemu ptasiemu gościowi z poematu The Raven. Metaforyczne i złowieszcze zarazem wycie wichru i ślady kruczych pazurów na kanadyjskim śniegu zdaje się jednak dostrzegać tylko Danny Smiřický. Twórczość E. A. Poego nudzi kanadyjską młodzież, przyzwyczajoną do oglądania w telewizji bardziej drastycznych horrorów. Nic jej nie zaskakuje, nic nie jest jej w stanie przerazić, pewne emocje budzi co najwyżej wzruszenie, którego Danny nie potrafi ukryć. Studenci z zaciekawieniem obserwują ten, w ich mniemaniu tani, sentymentalizm, uznając go za przerysowany efekt wywołany przez kiczowate, pełne niepotrzebnego patosu i ornamentyki strofy poematu The Raven. To, czego nie dostrzegaja, a nie

16 E.A. Poe, The Raven, http://www.heise.de/ix/raven/Literature/Lore/TheRaven. html / dostęp: 10.02.2011. 
dostrzegając, nie odczuwaja, to nostalgia wywołana słynnym nevermore, wypowiedzianym w innej rzeczywistości, w oddaleniu, w odseparowaniu, oderwaniu. Nevermore jest odpowiedzią na poczucie bezpowrotnie straconej młodości i możliwości twórczych, echem emigracyjnych myśli o utraconej ojczyźnie. Danny odczuwa coś na kształt bezwarunkowego odruchu wspominania, wywołanego poezją, która uderza w struny narodowych i osobistych doświadczeń, choć pisana była ponad sto lat wcześniej. Jej aktualność zostaje podkreślona niemal na każdym kroku, chociażby przez ciągłe pojawianie się w zasięgu wzroku (bądź ,w zasięgu wyobraźni”) Smiřrickiego ponuro drepczącego kruka, który co prawda nie mówi nic, ale doskonale wiadomo, co mógłby powiedzieć.

Danny stara się urozmaicić zajęcia poświęcone twórczości Edgara Allana Poego i swoje próby, by wytłumaczyć niewytłumaczalne, przywołując rosyjską parafrazę Kruka, autorstwa Jesenina Wolpina ${ }^{17}$. „Czas tierrora” razem z frazą „karknuł woron «Nevermore»” i poruszające brzmienie „r” nieobecne w angielskim oryginale, nie przynoszą jednak oczekiwanego efektu. Zajęcia owocują zaskakującymi pracami domowymi, w wśród nich absolutnym faworytem jest opracowany przez gorliwą studentkę Wendy ,albumo-komiks”, oprócz wielu barwnych (w sensie dosłownym i przenośnym) elementów, zawierający na stronie końcowej podobiznę Ligei, w której oku, z braku kruka, czai się zminiaturyzowana podobizna pingwina.

Zapłatą za decyzję o możliwości pisania bez cenzury i życia na emigracji jest wieczna świadomość owego nevermore, odnoszącego

17 Na szczególną uwagę zasługują funkcje przypisane pojawiającym się na kartach powieści językom - ich swoista stereotypizacja sprawia, że każdy z etnolektów reprezentuje określone wartości. Język rosyjski z jednej strony sygnalizuje czy nawet symbolizuje słowiańskość, z drugiej zaś jest znakiem smutku, melancholii. Przy okazji omawiania wspomnianej rosyjskiej peryfrazy wiersza Poego - jawi się jako język „wysoki”, idealny do tworzenia poezji. Jednak w całej powieści Škvoreckiego bywa on w większości użyty (na równi z językiem niemieckim) w sposób ironiczny i prześmiewczy, zaś jego zapis w zniekształconej formie wywołuje wrażenie językowej manifestacji, swoistego lingwistycznego oporu. Język niemiecki oraz język rosyjski pojawiają się niemal zawsze w kontekście utraty wolności, manipulacji, zniewolenia, ideologicznej indoktrynacji, ale także oportunizmu czy podporządkowania; więcej o wielojęzyczności tekstów Škvoreckiego można znaleźć w opracowaniu Petra Mareša, „Also Nazdar!’Aspekty textové vícejazyčnosti, Praha 2003. 
się do rzeczywistości pozostawionej, opuszczonej, do ojczyzny i wciąż żyjących w niej przyjaciół. Ale wygłos Poeowskiej frazy jest szczególnie uwydatniony w końcowych fragmentach powieści, w ostatnim rozdziale, którego duchowym patronem pozostaje Lovecraft. Motto tej części, a jednocześnie klamrę zamykającą fabułę Př́běhu... stanowi fragment tekstu Ulalume Edgara Allana Poego. Tu znów pojawia się wszechobecny kruk, przypominający o wiecznym nevermore, ale już w innym, bardziej uniwersalnym kontekście. ,Lonesome October” sprzyja wspominaniu i Danny po raz kolejny zanurza się w dniach, „when his heart was volcanic"18. Lektura Ulalume staje się sposobem na powrót do lat młodości i jednocześnie czasów pierwszej prawdziwej miłości Danny'ego, przedwcześnie zmarłej na gruźlicę Nadii Jirouškovej. Śmierć młodej, pięknej dziewczyny to jeden z wielu kresów podsumowujących opowieść o czeskiej historii przez pryzmat kanadyjskiej teraźniejszości. Przy dźwiękach Ulalume zamykają się losy poszczególnych postaci, przyjaciół i znajomych Danny’ego. Lejtmotywem staje się przyszłość, jedyną pewną rzeczą - śmierć. Wywołany z przeszłości nekrolog, zawiadamiający o śmierci Nadii w 1946 roku, zderzony zostaje z wiadomością od emigracyjnej przyjaciółki Smiřickiego Veroniki, która postanowiła wrócić do Czechosłowacji, a komentarzem oceniającym ten wybór jest wysłany przez nią do Kanady telegram o wymownej treści: „JA VUL STOP VERONIKA"19. Zestawienie tych dwóch „ostateczności” staje się wyrazistym, dość defetystycznym podsumowaniem uniwersalnych dążeń w życiu każdego człowieka i dydaktycznych oczekiwań Danny’ego

18 (...) It was night in the lonsome October

Of my most immemorial year:

It was hard by the dim lake of Auber,

In the misty mid region of Weir-

It was down by the dank tarn of Auber,

In the ghoul-haunted woodland of Weir.

Here once, through and alley Titanic,

Of cypress, I roamed with my Soul-

Of cypress, with Psyche, my Soul.

These were days when my heart was volcanic...(...)

E. A. Poe, Ulalume, http://en.wikisource.org/wiki/Ulalume / dostęp: 10.02.2011.

19 J. Škvorecký, Př́běh inženýra ..., cz. II, op. cit., s. 346. 
wobec własnych studentów. Jeszcze wyraźniejszą rekapitulacją emigracyjnych myśli byłaby jednak wyrwana $\mathrm{z}$ kontekstu fraza zaczerpnięta z Ulalume, brzmiąca: „what demon has tempted me here...” ${ }^{20}$. „Here”, to miejsce, emigracja, przestrzeń obca, choć oswojona. Ale „here”, to także pamięć i gnieżdżące się w niej wspomnienia, powracające w najmniej odpowiednich momentach, w całkowicie nieprzewidzianych sytuacjach.

\section{Nathaniel Hawthorne}

Czyż nie potraficie sobie wyobrazić, że ktoś może myśleć o świecie przychylnie i chcieć jego dobra na podstawie zupetnie innych idei niż te, które wy wyznajecie?21

Nawiązanie do romantyzmu, zrealizowane poprzez spotkanie z krukiem, Ulalume czy Pymem, nie pozostaje jedynym w Př́běhu odniesieniem do tej epoki w historii literatury światowej. Intelektualny opór studentów motywuje Danny'ego do poszukiwania odniesień bliższych gustom literackim zachodniej młodzieży. Kierując się przeczuciem, podpowiadającym, że masowa literatura może lepiej dotrzeć do młodej, niedoświadczonej wyobraźni, bohater stara się (z różnym skutkiem) zaktualizować przestrzeń i czas obecny w Szkarlatnej literze Hawthorne'a, dyskutując z utartym akademickim odczytaniem powieści, skupionym na rozpoznaniu symboliki kolorów czy ocenie poszczególnych bohaterów. Smiřický swoje interpretacyjne zamiary odkrywa przed studentami, proponując im temat pracy pisemnej: „Co ze Szkartatnej litery jest relewantne dla czasów współczesnych?”. Wyniki studenckich obserwacji nie zaskakują wykładowcy ${ }^{22}$, pozytywne wrażenie wywołuje jednak wystąpienie Ireny Svensson, która ogranicza

${ }^{20}$ E. A. Poe, Ulalume, op. cit.

${ }_{21}$ N. Hawthorne, Szkarłatna litera, przeł. B. Bałutowa, Warszawa 1982.

22 Jeden ze studentów za relewantną uznaje na przykład pruderię seksualną, autorka wspomnianego wcześniej komiksu, Wendy, nie odpowiada na pytanie, gdyż nie rozumie znaczenia słowa „relewantny”. 
krytyczne komentarze dotyczące powieści na rzecz konkretnego i, na tle pozostałych wypowiedzi, niebywale odkrywczego stwierdzenia:

Já ale myslím, že tato pasáž má platnost mnohem širší a je i pro součastnost a pro svět, $v$ němž žijeme relevantní. V některých zemích dosud platí intelektuální nonkonformismus za zločin těžší než sprosté zločiny, o sexuální morálce ani nemluvě²3.

Rozumna konkluzja Ireny wywołuje u Danny'ego poczucie długo wyczekiwanej ulgi. Jego samowolne odejście od ustalonych interpretacyjnych kanonów zaczyna przynosić skutek, a dostrzeganie przez studentów „,uchodźczej aureoli”, przestaje wynikać tylko z przeczucia, że stojący przed nimi człowiek z dziwnym akcentem przeżył w życiu coś ważnego. Ukojenie jest jednak chwilowe, podobnie jak chwilowe są intelektualne „zrywy” studentów, starających się pojąć, na czym polegaja geograficzne i światopoglądowe bariery.

\begin{abstract}
Zazoufal jsem v duchu nad zástupy studentů, kteří nemají profesorem americké literatury člověka odtamtud, ale někoho z Harvardu, jenž v hodinách věnovaných funkci barev v Šarlatovém písmenu skutečně probírá funkci barev v Šarlatovém písmenu. Asi to pro ně pro všechny navždy zůstane biograf. Ne navždy. Do pádu zapadního světa ${ }^{24}$.
\end{abstract}

Opisany w powieści Hawthorne'a purytanizm Nowej Anglii, przypomina w interpretacji Danny'ego mechanizmy funkcjonujące w komunistycznej Czechosłowacji. Danny stara się naprowadzić swoich studentów na właściwy (a przynajmniej przez niego oczekiwany) trop, pozwalając na zestawienie roli doktryny kościelnej, wpisanej w romantyczny tekst literacki, oraz fanatyzmu obecnego w ideologiach politycznych funkcjonujących w pewnych zakątkach świata. Kolejnych dowodów na powtarzalność życiowych i literackich schematów dostarcza emigracyjna rzeczywistość. Odbywający się przed niezawisłym trybunałem proces jednego z czeskich emigrantów, sądzonego za ucieczkę

\footnotetext{
23 Ibidem, s. 113.

24 Ibidem, s. 84.
} 
z Czechosłowacji (a tym samym złamanie prawa, które obowiązuje w jego ojczyźnie), konotuje jednoznaczne skojarzenia („,...stísněně jsem naslouchal, jak se muž určený k deportaci snaží vylíčit sám sebe jako obět' téměř pronásledování křest'anů..." ${ }^{25}$ ), a powtarzane przez oskarżonego Milana tłumaczenie, że uciekł z ojczyzny, by znaleźć „fridm”, nie przekonuje ławy przysięgłych ani sędziny, która - jak konkluduje narrator - „vyhlížela jako volající žena z Hawthorna"26.

Kanadyjska rzeczywistość (w równej mierze jak świat za żelazną kurtyną) przesycona jest możliwościami odniesień do tekstu Hawthorne'a. Szczególnie ważne zdaje się odmienne rozumienie (bądź też niezrozumienie) symboli, znaków, ikon. Percy, jeden z kanadyjskich ładnych, miłych i porządnych chłopców, który za wszelką cenę stara się udowodnić czeskim znajomym, że zachodni raj nie jest wcale taki niebiański, jest posiadaczem wisiorka z symbolem, o którego znaczeniu wie dokładnie tyle, ile o wszystkim - zgodnie z sugestią Danny’ego, Percy nie ma pojęcia o niczym. Alternatywne odczytanie szkarłatnego symbolu na piersi Hester (Adultery, Angel, Able, Admirable) pozwala dostrzec wieloznaczność wisiorka zawieszonego na szyi Percy’ego. Nie ma on pojęcia, że jego tajemniczy „amulet” symbolizuje pokój, tym bardziej nie może nawet przeczuwać, jak ów symbol interpretuje dziewczyna z Europy Środkowej, Veronika...

„Protože já jsem zaujatá taky proti revoluci” pohlédne ostře na Percyho neviňoučký obličej. „Sorry to hurt your political feelings, if any". Percy pohled nepochopí. Netuší, že hněv vyvolal amulet, o němž neví, že znamená Mír, a o němž holka ví, že když se to hodí, může znamenat taky válku, spravedlivou, nebot' taková je dialektika. Percy nic takového neví. Netušši ${ }^{27}$.

Zarówno niewiedza, jak i różnorodność interpretacji (symboli, znaków, a także literatur) wynikają rzecz jasna z różnorodności światów, w których żyją bohaterowie. Z przeczuć i doświadczeń, jakie zdobyli lub nie. $\mathrm{Z}$ istnienia bądź nieistnienia duchów przeszłości. Dlatego pa-

\footnotetext{
25 Ibidem, s. 94.

26 Ibidem.

27 Ibidem, s. 139.
} 
cyfka bywa ładną ozdobą, a „Triumf woli” Leni Riefenstahl, to pierwszy film w dziejach kinematografii, który nakręciła kobieta ${ }^{28}$. Dlatego jeden ze studentów arabskiego pochodzenia - Hakim (jak przedstawia go narrator - fanatyczny dogmatyk, przypominający do złudzenia pana Dimmesdale) odnosi do Ameryki zdanie: ,ze wszystkich możliwych hipokryzji niewątpliwie udało nam się osiagnąć tę najbardziej jałową, kiedy próbowaliśmy wprowadzić jedynie słuszny system"29. Dlatego lekcja literatury staje się lekcją historii. Dlatego też Danny niezwykle często żałuje, że nie zawsze podczas seminarium, rozmowy, wykładu czy życia, można powiedzieć „,class is dismissed”.

\section{Literatura}

Chvatík K., Opowiadacz Škvorecký, przeł. A. S. Jagodziński, „Literatura na Świecie" 2007, nr 3-4, s. 257-271.

Hawthorne N., Szkarłatna litera, przeł. B. Bałutowa, Warszawa 1982.

Jazz w małym mieście. Z Josefem Škvoreckim rozmawia Antonín J. Liehm, przeł. T. Grabiński, „Literatura na Świecie” 2007, nr 3-4, s. 311-333.

Kosková H., Josef Škvorecký, Praha 2004.

Poe E. A., The Raven, http://www.heise.de/ix/raven/Literature/Lore/TheRaven. html / dostęp: 10.02.2011.

Poe E. A., Ulalume, http://en.wikisource.org/wiki/Ulalume / dostęp: 10.02.2011.

Škvorecký J., Přiběh inženýra lidských duši, Praha 1998.

Škvorecký J., Przypadki inżyniera ludzkich dusz. Entertainment ze starymi tematami życia, kobiet, losu, marzeń, klasy robotniczej, tajniaków, miłości $i$ śmierci, przeł. A. S. Jagodziński, Sejny 2008.

Škvorecký J., Př́běh neúspěšného saxofonisty, Praha 1997.

Żmigrodzka M., Janion M., Romantyzm i historia, Warszawa 1978.

28 „«Co to bude za film?» ptám se. «Triumph of the Will. Leni - Reefen - something». "Anebo já půjdu s váma, jestli můžu», rozhoduje se najednou Veronika opačně. «Sure», praví Irena Svenssonová. «Moje sestra říká, že to je první umělecký film v dějinách kinematografie, který natočila žena». A máme to" - J. Škvorecký, Příběh inženýra..., cz. 1, op. cit., s. 117.

${ }^{29}$ Cyt za: J. Škvorecký, Przypadki..., op. cit., s. 119. 